\title{
PENDIDIKAN KARAKTER MELALUI PEMBELAJARAN SASTRA
}

\author{
Maman Suryaman \\ FBS Universitas Negeri Yogyakarta (e-mail: maman_surya@yahoo.com; \\ HP. 081321775597)
}

\begin{abstract}
Character Education through Literature Learning. One of the important aspects in appropriate literature learning is character education. Based on the results of several studies, some conclusions can be drawn. First, essentially literature is a medium of mental and intellectual enlightenment, the most important aspect in character education. Second, there are a variety of literary works that need appreciating as they are important in the character development. Third, literature learning relevant to the character development is one that enables learners to develop their awareness of reading and writing as important prerequisites for the character development. Fourth, literary books relevant to the character development are those with beautiful language capable of making the readers moved, containing high humanistic values, and encouraging the readers to treat other people and creatures well.
\end{abstract}

Keywords: literature, literature learning, character education

\section{PENDAHULUAN}

Undang-undang Dasar Negara Republik Indonesia Tahun 1945 mengamanatkan agar pemerintah mengusahakan dan menyelenggarakan satu sistem pendidikan nasional yang mengarah kepada peningkatan keimanan dan ketakwaan kepada Tuhan Yang Maha Esa serta akhlak mulia dalam rangka mencerdaskan kehidupan bangsa. Pencapaian amanat ini secara teoretis dapat dicermati secara komprehensif melalui peningkatan kecerdasan intelektual, kecerdasan emosional, dan kecerdasan spiritual.

Dilihat dari kacamata pendidikan, peningkatan tersebut haruslah diterjemahkan secara operasional dan diimplementasikan melalui proses pembela- jaran yang memadai. Pembelajaran yang memadai bukan hanya mengembangkan salah satu kecerdasan, akan tetapi seluruh kecerdasan manusia.

Kecerdasan manusia secara operasional dapat digambarkan melalui tiga dimensi, yakni kognitif, psikomotorik, dan afektif. Melaluipengembangan kognitif, kapasitas berpikir manusia harus berkembang. Melalui pengembangan psikomotorik, kecakapan hidup manusia harus tumbuh. Melalui pengembangan afektif, kapasitas sikap manusia harus mulia. Hal ini sejalan dengan dasar pendidikan Indonesia, yakni mencerdaskan bangsa yang beriman dan bertakwa serta berakhlak mulia. Dengan kata lain, peserta didik bersekolah bukan hanya untuk menghadapi bahas- 
an soal-soal ujian; peserta didik bersekolah merupakan strategi untuk mempersiapkan dirinya memasuki kehidupan di masa kini dan masa yang akan datang yang lebih baik.

Secara empiris, pelaksanaan pembelajaran masih diarahkan kepada pencerdasan yang bersifat kognitif. Pada tataran ini pun, kecerdasan intelektual yang bersifat kognitif masih terbatas kepadapengembangankemampuan menghafal atau transfer pengetahuan dan keterampilan menyelesaikan soal-soal ujian. Pengembangan kognitif yang lainnya masih diabaikan, misalnya, pengembangan kognitif untuk meningkatkan daya kritis. Sebagai gambaran dapatlah dikemukakan hasil studi The International Association for the Evaluation of Education Achievement (Elley, 1992). Data tersebut menunjukkan bahwa siswa SD Indonesia dalam hal kemampuan bacanya berada pada urutan ke26 dari 27 negara yang diteliti. Hal yang sama dilaporkan pula oleh World Bank (1998) bahwa kemampuan membaca siswa Indonesia berada pada urutan kelima dari lima Negara Asia yang diteliti.

Data termutakhir dari laporan UNESCO (2003) melalui Program for International Student Assessment (PISA) menunjukkan bahwa keterampilan membaca anak-anak Indonesia usia 15 tahun ke atas, berada pada urutan ke-39 dari 41 negara yang diteliti. Berita yang dilansir oleh Harian Umum Pikiran Rakyat (Pikiran Rakyat, 5 Agustus 2005) tentang kondisi ideal surat kabar yang harus dibaca, yakni 1:10 atau satu surat kabar untuk 10 penduduk, belum dicapai oleh masyarakat Indonesia. Bahkan, masih di bawah Filipina dan Sri Langka dengan rasio sebagai berikut: Indonesia 1:45; Filipina 1:30; dan Sri Langka 1:38.

Kondisitersebutmencerminkan bahwa kebutuhan dan kemampuan membaca masyarakat Indonesia sebagai pondasi awal bagi pembentukan karakter masih sangat rendah. Oleh karena itu, untuk menciptakan agar masyarakat memiliki kebutuhan akan buku, melek aksara harus terus diciptakan. Penciptaan ini sejalan dengan kesepakatan Dakar (Global Monitoring Report, 2006) tentang Literacy for Life bahwa keberaksaraan merupakan hak seluruh umat manusia tidak hanya karena alasan moral, tetapi juga untuk menghindari hilangnya potensi manusia dan kapasitas ekonomi yang menjadi esensi fundamental dari pendidikan karakter.

Kondisi tersebut juga mencerminkan bahwa berbagai persoalan yang muncul di dalam pendidikan yang belum kuat secara kemanusiaan akan melemahkan kepribadian bangsa. Semangat untuk belajar, berdisiplin, beretika, bekerja keras, dan sebagainya akan menurun. Peserta didik banyak yang tidak siap untuk menghadapi kehidupan sehingga dengan mudah meniru budaya luar yang negatif, terlibat di dalam amuk massa, melakukan kekerasan di sekolah atau kampus, dan sebagainya. Di sisi lain, tontonan yang dipertunjukkan oleh orang-orang dewasa, seperti di "panggung" politik, di dalam birokrasi pemerintahan,didalam kehidupan kampus, dan di seputar kehidupan masyarakat belumlah dapat dijadikan model kehidupan yang ideal seperti yang diamanatkan oleh UUD 1945. Meningkatnya kemiskinan, menjamurnya budaya 
korupsi, munculnya plagiarisme, menguatnya politik uang, dan sebagainya sebagai cerminan dari kehidupan yang tidak berkarakter kuat untuk menuju bangsa yang berperadaban maju.

Fenomena-fenomena empiris tersebut haruslah segera disadari oleh para pendidik bahasa Indonesia. Wujud dari kesadaran itu adalah dikembangkannya berbagai strategi untuk meningkatkan pembelajaran bahasa Indonesia. Salah satu di antaranya adalah pembelajaran sastra dapat dijadikan sebagai media di dalam pengembangan karakter peserta didik. Oleh karena itu, pada artikel ini akan dipaparkan mengenai hakikat karya sastra dan pendidikan karakter, materi bersastra di dalam kurikulum yang mengarah pada pengembangan karakter, serta pembelajaran bersastra yang relevan untuk membangun karakter peserta didik.

\section{HAKIKAT KARYA SASTRA DAN PENDIDIKAN KARAKTER}

Sastra sebagai cerminan keadaan sosial budaya bangsa haruslah diwariskan kepada generasi mudanya. Menurut Herfanda (2008:131), sastra memiliki potensi yang besar untuk membawa masyarakat ke arah perubahan, termasuk perubahan karakter (pen.). Sebagai ekspresi seni bahasa yang bersifat reflektif sekaligus interaktif, sastra dapat menjadi spirit bagi munculnya gerakan perubahan masyarakat, bahkan kebangkitan suatu bangsa ke arah yang lebih baik, penguatan rasa cinta tanah air, serta sumber inspirasi dan motivasi kekuatan moral bagi perubahan sosialbudaya dari keadaan yang terpuruk dan 'terjajah' ke keadaan yang mandiri dan merdeka.

Tentulah spirit-spirit tersebut menjadi bagian terpenting dari pendidikan karakter peserta didik. Artinya, sastra tidak hanya sekadar menjadi sesuatu yang mampu memberikan kemenarikan dan hiburan serta yang mampu menanamkan dan memupuk rasa keindahan, tetapi juga yang mampu memberikan pencerahan mental dan intelektual. Dalam keadaan demikian, menurut Ismail dan Suryaman (2006) sastra haruslah sudah diperkenalkan kepada anak sejak usia dini. Hal ini dimaksudkan agar kemampuan literasi tumbuh sehingga budaya baca berkembang. Kemampuan literasi tidak dapat tumbuh tanpa usaha sadar dan terencana. Usaha sadar dan terencana itu di antaranya adalah melalui penyediaan sarana dan prasarana baca, seperti buku dan perpustakaan, yang dapat dimulai dari buku-buku sastra.

Selain mengandung keindahan, karya sastra juga memiliki nilai manfaat bagi pembaca. Segi kemanfaatan muncul karena penciptaan karya sastra berangkat dari kenyataan sehingga lahirlah paradigma bahwa sastra yang baik menciptakan kembali rasa kehidupan, baik bobotnya maupun susunannya; menciptakan kembali keseluruhan hidup yang dihayati: kehidupan emosi, kehidupan budi, individu maupun sosial, serta dunia yang sarat objek (Ismail dan Suryaman, 2006). Penciptaannya dilakukan bersama-sama dan secara saling berjalinan, seperti terjadi dalam kehidupan yang kita hayati sendiri. Namun, kenyataan ini di dalam sastra dihadirkan melalui proses kreatif. 
Artinya, bahan-bahan tentang kenyataan telah dipahami melalui proses penafsiran baru dalam perspektif pengarang. Karya sastra memang merupakan dokumen sosial, yang lebih dahulu disebut jalan keempat ke Kebenaran: melalui sastra pembaca seringkali jauh lebih baik daripada melalui tulisan-tulisan nonsastra serta dapat menghayati hakikat eksistensi manusia dengan segala permasalahannya. Di sinilah segi keindahan dan kebermanfaatan dari karya sastra, yakni gambaran kenyataan dalam subjektivitas pengarang. Kenyataan di dalam karya sastra ibarat bahan-bahan untuk membuat "sop buntut". "Sop buntut" yang siap disantap adalah karya sastra. Rasa, aroma, dan kekhasannya adalah hasil dari subjektivitas "sang koki".

Secara teori, Abrams (1981) telah memberikan pemetaan mengenai karya sastra ke dalam empat paradigma. Paradigma pertama adalah mengenai karya sastra sebagai karya objektif (sesuatu yang otonom, terlepas dari unsur apa pun). Paradigma kedua adalah mengenai karya sastra sebagai karya mimesis (tiruan terhadap alam semesta). Paradigma ketiga adalah mengenai karya sastra sebagai karya pragmatis (yang memberikan manfaat bagi pembaca). Paradigma keempat adalah mengenai karya sastra sebagai karya ekspresif (pengalaman dan pemikiran pencipta). Dengan demikian, karya sastra memang memiliki segi manfaat bagi pembaca, khususnya berkenaan dengan nilai-nilai yang terkandung di dalamnya agar pembaca lebih mampu menerjemahkan persoalan-persoalan hidup melalui kesalehan sosial dan kesalehan ritual.

Berdasarkan paparan tersebut dapatlah disimpulkan bahwa sastra dengan demikian dapat berfungsi sebagai media pemahaman budaya suatu bangsa (yang di dalamnya terkandung pula pendidikan karakter). Melalui novel, misalnya, model kehidupan dengan menampilkan tokoh-tokoh cerita sebagai pelaku kehidupan menjadi representasi dari budaya masyarakat (bangsa). Tokoh-tokoh cerita adalah tokoh-tokoh yang bersifat, bersikap, dan berwatak. Kita dapat belajar dan memahami tentang berbagai aspek kehidupan melalui pemeranan oleh tokoh tersebut, termasuk berbagai motivasi yang dilatari oleh keadaan sosial budaya tokoh itu. Hubungan yang terbangun antara pembaca dengan dunia cerita dalam sastra adalah hubungan personal. Hubungan demikian akan berdampak kepada terbangunnya daya kritis, daya imajinasi, dan rasa estetis. Melalui sastra, peserta didik tidak hanya belajar budaya konseptual dan intelektualistis, melainkan dihadapkan kepada situasi atau model kehidupan konkret. Sastra dapat dipandang sebagai budaya dalam tindak (culture in action), dan membaca sastra Indonesia misalnya, berarti mempelajari kehidupan bangsa Indonesia.

Tentulah fungsi sastra tersebut perlu mendapatkan penegasan di dalam orientasi penciptaannya agar terbangun karakter yang kuat bagi pembaca. Menurut Herfanda (2008:132) bentuk penegasan di dalam penciptaan sastra perlulah diorientasikan kepada hal-hal yang bersifat pragmatik, yakni orientasi pada kebermanfaatan sastra sebagai 
media pencerahan dan pencerdasan masyarakat. Herfanda (2008:133) mempertegasnya dengan memaparkan pemikiran Sutan Takdir Alisyahbana (STA) yang dipandangnya sebagai tokoh renaisans Indonesia. Di dalam bersastra, STA memilki prinsip bahwa seni sastra bukan sekadar untuk seni, tetapi juga untuk kebermanfaatan intelektual dan pencerdasan masyarakat. Oleh karena itu, menurut STA, sastra tidaklah bisa bermewah-mewah dengan keindahan untuk mencapai kepuasan seseorang dalam mencipta, tetapi harus dilibatkan secara aktif dalam seluruh pembangunan bangsa. Sastra haruslah membuat pembaca lebih optimis dan mampu menghadapi hidup dengan semangat juang yang tinggi untuk mengatasi berbagai masalah dan situasi kritis. STA membuktikannya melalui novel Layar Terkembang serta novel Kalah dan Menang.

\section{MATERI BERSASTRA DI DALAM KURIKULUM YANG MENGARAH PADA PENGEMBANGAN KARAK- TER}

Materi sastra di dalam kurikulum dapat dikenali melalui standar isi (SI) yang dikembangkan oleh BSNP (Permendiknas No. 22 Th. 2006). Di di dalam SI terdapat standar kompetensi (SK) mata pelajaran Bahasa Indonesia yang merupakan kualifikasi kemampuan minimal peserta didik yang digambarkan melalui penguasaan pengetahuan, keterampilan, dan sikap positif terhadap bahasa dan sastra Indonesia. Standar kompetensi ini merupakan dasar bagi peserta didik untuk memahami dan merespons situasi lokal, regio- nal, nasional, dan global.

Dengan standar kompetensi ini terdapat beberapa harapan yang ditumpukan kepada mata pelajaran Bahasa Indonesia, yakni sebagai berikut.

- Peserta didik dapat mengembangkan potensinya sesuai dengan kemampuan, kebutuhan, dan minatnya,serta dapatmenumbuhkan penghargaan terhadap hasil karya kesastraan dan hasil intelektual bangsa sendiri.

- Pendidik dapat memusatkan perhatian kepada pengembangan kompetensi bahasa peserta didik dengan menyediakan berbagai kegiatan berbahasa, bersastra, dan sumber belajar.

- Pendidik lebih mandiri dan leluasa dalam menentukan bahan ajar kebahasaan dan kesastraan sesuai dengan kondisi lingkungan sekolah dan kemampuan peserta didiknya.

- Orang tua dan masyarakat dapat secara aktif terlibat dalam pelaksanaan program kebahasaan dan kesastraan di sekolah.

- Sekolah dapat menyusun program pendidikan tentang kebahasaan dan kesastraan sesuai dengan keadaan peserta didik dan sumber belajar yang tersedia.

- Daerah dapat menentukan bahan dan sumber belajar kebahasaan dan kesastraan sesuai dengan kondisi dan kekhasan daerah dengan tetap memperhatikan kepentingan nasional.

Menurut Permendiknas No. 22 Th. 2006 mata pelajaran Bahasa Indonesia bertujuan agar peserta didik memiliki kemampuan sebagai berikut. 
- Berkomunikasi secara efektif dan efisien sesuai dengan etika yang berlaku, baik secara lisan maupun tulis.

- Menghargai dan bangga menggunakan bahasa Indonesia sebagai bahasa persatuan dan bahasa negara.

- Memahami bahasa Indonesia dan menggunakannya dengan tepat dan kreatif untuk berbagai tujuan.

- Menggunakan bahasa Indonesia untuk meningkatkan kemampuan intelektual, serta kematangan emosional dan sosial.

- Menikmati dan memanfaatkan karya sastra untuk memperluas wawasan, memperhalus budi pekerti, serta meningkatkan pengetahuan dan kemampuan berbahasa.

- Menghargai dan membanggakan sastra Indonesia sebagai khazanah budaya dan intelektual manusia Indonesia.

Berdasarkan harapan dan tujuan tersebut, penekanan pembelajaran sastra berorientasi pada manfaat sastra bagi pengembangan karakter peserta didik, di samping tentulah manfaat estetis. Penekanan ini menjadi bagian terpenting di dalam pembelajaran bersastra yang meliputi kegiatan mendengarkan, berbicara, membaca, dan menulis. Oleh karena itu, kegiatan bersastra ditujukan untuk meningkatkan apresiasi terhadap sastra agar peserta didik memiliki kepekaan terhadap sastra yang baik dan bermutu yang akhirnya berkeinginan membacanya.

Permasalahan terbesar dan mendasar di dalam pembelajaran bersastra saat ini adalah permasalahan berkenaan dengan kemampuan dan kebiasaan membaca dan menulis. Mengingat beta- pa pentingnya permasalahan ini untuk segera dipecahkan dan betapa besarnya dampak bagi pengembangan mutu pendidikan, Pemerintah melakukan pengaturan secara khusus melalui Peraturan Pemerintah (PP). Di dalam PP No. 19 Th. 25 Pasal 26 Ayat 3 disebutkan bahwa "Kompetensi lulusan untuk mata pelajaran bahasa menekankan pada kemampuan membaca dan menulis yang sesuai dengan jenjang pendidikan". Kemudian, pada Pasal 21 Ayat 2 diatur pula bahwa "Perencanaan proses pembelajaran dilakukan dengan mengembangkan budaya membaca dan menulis". Pengaturan ini berkorelasi dengan hasil pemetaan di atas, yakni pembelajaran membaca dan menulis di dalam kegiatan bersastra memang mendapatkan porsi yang lebih banyak daripada mendengarkan dan berbicara. Hal ini mengindikasikan bahwa pembelajaran membaca dan menulis harus mendapatkan perlakuan khusus dari para pendidik bahasa Indonesia.

Kegiatan bersastra memerlukan pula pemahaman yang baik dari pendidik berkenaan dengan fungsi utama sastra yang termasuk dalam kelompok mata pelajaran estetika. Fungsi utama sastra adalah untuk penghalusan budi, peningkatan rasa kemanusiaan dan kepedulian sosial, penumbuhan apresiasi budaya, penyaluran gagasan, penumbuhan imajinasi, serta peningkatan ekspresi secara kreatif dan konstruktif. Pembelajaran sastra dalam mata pelajaran Bahasa Indonesia bertujuan untuk meningkatkan kemampuan peserta didik dalam menikmati, menghayati, dan memahami karya sastra. Namun, kegiatan bersastra juga belum berkem- 
bang secara maksimal oleh karena kemampuan dan kebiasaan membaca dan menulis mereka masih relatif rendah. Temuan Ismail (2003) menunjukkan bahwa peserta didik tidak membaca karya sastra alias nol judul per tahun. Padahal, mereka diwajibakan untuk membacanya sebanyak 15 judul buku karya sastra.

Masyarakat pada umumnya beranggapan bahwa membaca sudah dikuasai selepas masa kanak-kanak yang ditandai dengan dapat mengenali huruf-huruf tertulis. Pandangan ini berdampak negatif bagi pengembangan budaya masyarakat. Mereka tidak perlu lagi belajar membaca melalui kegiatan membaca berbagai karya sastra. Sebagian besar keluarga pun tidak menyediakan buku dan mengondisikan anakanaknya untuk membaca selepas tamat sekolah dasar. Pandangan ini terus berlanjut pada generasi berikutnya. Bahkan, pandangan ini terus dianut oleh para pendidik, termasuk pendidik bahasa Indonesia.

Di dalam konteks budaya masyarakat seperti ini, Kleden (1999:8-9) mengelompokkan penduduk Indonesia ke dalam tiga jenis. Pertama, penduduk yang secara teknis dapat membaca dan menulis kalau diminta membacakan atau menuliskan nama, tempat kelahiran, nama orang tua, dan jenis pekerjaan. Inilah orang-orang yang telah mendapat latihan membaca-menulis. Akan tetapi, karena bahan bacaan yang tersedia sedemikian langka, mereka jarang sekali mempraktikkan kemampuan membacanya. Dengan kata lain, orangorang ini secara teknis dapat membaca (dan barangkali dapat menulis). Kedua, penduduk yang secara teknis dan fungsional dapat membaca dan menulis. Misalnya, anak-anak sekolah yang harus sanggup membaca buku (teks) pelajaran, orang-orang keuangan di suatu lembaga atau perusahaan yang harus membaca dan menuliskan pemasukan dan pengeluaran, atau seorang insinyur otomotif akan membaca buku petunjuk mobil. Bagi kelompok ini, membaca dan menulis adalah sebuah fungsi yang harus dijalankan dalam konteks pekerjaan. Mereka belum menjadikan membaca dan menulis sebagai kebiasaan untuk berkomunikasi dan berekspresi melalui tulisan. Ketiga, penduduk yang di samping mempunyai kesanggupan baca-tulis secara teknis dan fungsional, menjadikan bacatulis sebagai kebutuhan hidup seharihari. Mereka tidak hanya membaca dan menulis dengan hal-hal yang terkait dengan pekerjaan, tetapi oleh kebutuhan secara budaya.

Kalau pengelompokan tersebut dihubungkan dengan data mengenai kemampuan membaca dan menulis, kemungkinan besar kemampuan yang dimaksud adalah kemampuan dalam kelompok pertama, yakni kesanggupan dalam hal kemampuan membaca dan menulis secara teknis. Kondisi demikian mencerminkan bahwa kemampuan serta kebiasaan membaca dan menulis peserta didik masih sangat rendah.

Jika menengok kegiatan bersastra yang dilakukan selama ini, sesungguhnya kurikulum telah memungkinkan peserta didik untuk mahir dan terbiasa membaca dan menulis. Yang menjadi persoalan adalah implementasinya di kelas maupun di rumah. Pendidik dan 
peserta didik menghabiskan relatif banyak waktu kegiatan kelasnya untuk keterampilan seperti bahasan kosakata, hubungan huruf-bunyi, dan jawaban terhadap pertanyaan secara tertulis. Relatif sedikit waktu yang dihabiskan untuk pendramatisasian cerita, membaca senyap mandiri prosa, menyimak cerita yang dibaca, membaca di perpustakaan, atau bekerja dalam kelompok kecil membaca. Peserta didik jarang diminta untuk membaca sesuatu di rumah sebagai bagian dari program sastranya. Bahkan, menurut Harjasujana (1988:11) dalam era kekinian, dengan kehadiran TV, aktivitas anak-anak di rumah lebih banyak berupa kegiatan menonton sehingga kegiatan membaca ataupun menulis tidak terjadi.

Selain membaca dan menulis, kemampuan bersastra lain yang harus dikembangkan adalah kemampuan mendengarkan dan berbicara. Melalui pembelajaran ini, peserta didik harus mampu menjadi pendengar dan pembicara yang handal. Kemampuan ini bukan semata-mata untuk kepentingan hubungan sosial dan pribadi, tetapi lebih jauh daripada itu, yakni untuk kepentingan mengembangkan karakter peserta didik yang siap menghadapi masa depan.

Esensi terpenting dari materi bersastra di dalam kurikulum adalah prinsip membaca dan menulis serta mendengarkan dan melisankan dengan penekanan pada membaca dan menulis sastra. Esensi ini sangat relevan dengan hakikat karya sastra dan program-program pembentukan karakter peserta didik. Relevansi itu tampak pada pembentukan mental dan intelektual mela- lui kegiatan membaca dan menulis serta penghalusan budi, peningkatan rasa kemanusiaan dan kepedulian sosial, penumbuhan apresiasi budaya, penyaluran gagasan, penumbuhan imajinasi, serta peningkatan ekspresi secara kreatif dan konstruktif. Oleh karena itu, penataan yang tepat terhadap materi bersastra secara efektif berperan di dalam pembentukan karakter peserta didik.

\section{PEMBELAJARAN B E R S A S T R A YANG RELEVAN BAGI PENGEM- BANGAN KARAKTER}

Di dalam pembelajaran bersastra dikehendaki terjadinya kegiatan bersastra, yaitu kegiatan menggunakan bahasa dan estetika (Rusyana dan Suryaman, 2005). Jadi, berbagai unsur sastra, seperti tokoh, penokohan, alur cerita, latar cerita di dalam prosa; unsur bentuk dan makna di dalam puisi; dialog dan teks pelengkap di dalam drama tidaklah diajarkan secara berdiri sendiri sebagai unsur-unsur yang terpisah, melainkan dalam susunan yang padu sebagai karya cipta yang indah di dalam kegiatan mendengarkan, kegiatan berbicara, kegiatan membaca, dan kegiatan menulis. Kegiatan mendengarkan, berbicara, membaca, dan menulis itu digunakan dalam kegiatan berapresiasi, yaitu oleh seseorang dalam berhubungan dengan karya sastra. Sastra di dalam kegiatan berapresiasi digunakan untuk bertukar pikiran, perasaan, pendapat, imajinasi, dan sebagainya sehingga terjadi kegiatan sambut-menyambut.

Kegiatan bersastra itu serempak dilakukan dalam kegiatan lain, baik kegiatan jasmani maupun kegiatan rohani. Kegiatan bersastra dilakukan se- 
rempak dengan kegiatan menggunakan tangan, kaki, kepala, pancaindra, dan sebagainya. Kegiatan bersastra pun dilakukan serempak dengan kegiatan merasa, berpikir, berimajinasi, dan sebagainya. Kegiatan bersastra serta kegiatan berbuat itu terjadi dalam konteks, berupa tempat, waktu, dan suasana. Di dalamnya terdapat tanah, air, udara, cahaya, tumbuhan, binatang; manusia dengan masyarakat dan budayanya, serta Tuhan dan alam ciptan-Nya. Bagian-bagian yang ada di dalam pembelajaran bersastra itulah yang dimaksud dengan konteks-konteks belajar.

Berdasarkan paparan tersebut dapat disimpulkan bahwa kegiatan bersastra yang efektif adalah kegiatan yang mengarah pada berapresiasi secara luas, bukan sebatas bahasan yang sifatnya kognitif. Hal ini sejalan dengan batasan menurut Effendi (1982:70) bahwa berapresiasi sastra adalah kegiatan menggauli cipta sastra dengan sungguhsungguh sampai menimbulkan pengertian, penghargaan, kepekaan pikiran kritis, dan kepekaan perasaan yang baik terhadap cipta sastra. Dengan demikian, tujuan pembelajaran bersastra adalah tumbuhnya pengertian, penghargaan, kepekaan pikiran kritis, dan kepekaan perasaan yang baik terhadap cipta sastra pada diri peserta didik.

Kegiatanberapresiasimeliputi membaca beragam karya sastra, mempelajari teori sastra, mempelajari esei dan kritik sastra, serta mempelajari sejarah sastra. Di samping itu, perlu pula dilakukan kegiatan pendokumentasian atas informasi mengenai karya sastra serta kegiatan kreatif, yakni menulis karya sastra dan menulis bahasan terhadap kar- ya sastra. Kegiatan-kegiatan seperti ini tentulah akan mengatasi kendala kurang tersedianya buku-buku sastra di perpustakaan sekolah.

Kegiatan pendokumentasian dan kegiatan kreatif itu dilihat dari segi pembelajaran ditujukan untuk meningkatkan apresiasi terhadap sastra agar peserta didik memiliki kepekaan terhadap sastra yang baik dan bermutu yang akhirnya berkeinginan membacanya. Hal ini sesuai dengan salah satu bentuk dari pembelajaran bersastra, yakni melalui kewajiban bagi peserta didik untuk membaca karya-karya sastra bermutu. Di seluruh negara di dunia, sekolah mewajibkan para peserta didiknya untuk membaca buku sastra (bukan bertujuan supaya peserta didik jadi sastrawan, tetapi agar terbentuk dan terlatih kebiasaan serta kesenangan membaca buku pada umumnya). Kewajiban ini dituangkan di dalam standar isi (SI) bahwa peserta didik SMA/ MA harus membaca buku sastra minimal 15 buah.

Dari pengamatan Taufiq Ismail (Ismail, 2003) di beberapa negara Asia Tenggara seperti Malaysia, Thailand, Singapura, dan Brunei Darussalam, peserta didik SMA wajib membaca dan memberikan ulasan terhadap 5-7 buku sastra dalam 3 tahun. Di Rusia Soviet, Kanada, Jepang, dan Swiss, kewajiban tersebut adalah 12-15 judul buku. Di Jerman Barat, Perancis, Belanda, dan Amerika Serikat masing-masing mewajibkan peserta didiknya membaca karya sastra masing-masing sebanyak 22, 30, 30 dan 32 judul. AMS Hindia Belanda (sebelum 1942) mewajibkan peserta didik membaca 25 judul karya sastra, se- 
taraf dengan Eropa dan Amerika hari ini.

Di zaman Republik Indonesia, dengan kriteria kurikulum, tersedianya buku di perpustakaan sekolah, buku dibaca tamat, peserta didik mengulasnya dan lalu diujikan, dibandingkan dengan negara-negara di atas, peserta didik SMAMA Indonesia membaca 0 (nol) buku sastra. Hal yang mengejutkan ini sudah berlangsung lebih dari 60 tahun, yakni sejak 1943. Peserta didik kita, untuk bisa lulus, cukup membaca ringkasan atau sinopsis novel, dan dengan demikian kenal nama-nama tokoh dan alur cerita, tetapi tidak pernah menikmati karya sastra secara utuh. Dengan demikian, generasi muda kita tidak mendapatkan manfaat pencerahan dan kecendekiaan dari karya sastra sebenarnya.

Tidak adanya kewajiban membaca buku sastra seperti sebelum 1943 terutama karena tidak disediakannya bukubuku sastra di perpustakaan sekolah. Hal ini merupakan kepincangan pertumbuhan peradaban bangsa kita yang tertinggal lama dan luar biasa parahnya. Bahkan, kondisi demikian memberikan gambaran pula bahwa pendidikan karakter di negeri ini tidak terjadi melalui pembelajaran sastra, dan tentu pula melalui pembelajaran-pembelajaran yang lain oleh karena peserta didik tidak membaca.

Peserta didik sejak TK sampai dengan SMA secara psikologis berada pada usia yang seharusnya mengalami masa membaca yang kuat oleh karena waktu luang mereka amat banyak dan cenderung akan menghabiskan waktu senggangnya untuk membaca bahan atas pilihan sendiri, seperti komik, majalah, atau surat kabar. Di masa ini pula orientasi pembentukan karakter sangat efektif dilakukan. Oleh karena itu, pengenalan yang memadai terhadap perkembangan kognitifnya amat penting untuk diperhatikan pendidik bahasa Indonesia.

Piaget (1971) menawarkan empat fase perkembangan kognitif, yakni sensorimotor, praoperasional, berpikir konkret, dan berpikir formal. Masing-masing fase tentulah memiliki karakteristik yang khas. Misalnya, peserta didik di tingkat SMP dilihat dari sisi usianya berkisar antara 12-15 tahun. Kelompok usia ini tergolong ke dalam masa remaja (adolescene), dan mulai memasuki tahap berpikir formal (formal operations). Pada tahap ini anak mulai mengembangkan kemampuan memecahkan masalah yang dapat diselesaikan melalui operasi logis.

Perubahan kognitif dari berpikir konkret ke berpikir logis berimplikasi bagi kegiatan pembelajaran bersastra. Jika pada mulanya peserta didik di dalam belajar bersastra didasari oleh pemikiran bahwa apa yang diindera itulah sesungguhnya kehidupan, pada masa remaja mereka akan mengubah haluan. Segala yang mereka indera akan mulai direkayasa dalam wujud dugaan-dugaan. Peserta didik akan mulai menggali sesuatu yang tidak tampak secara inderawi. Dalam posisi seperti ini, pendidik bahasa Indonesia haruslah membantu mereka untuk mengembangkanpenemuan-penemuan baru yang akan memperkaya pengalaman kognitifnya. 
Perhatian yang harus diberikan pendidik secara khusus di dalam pengembangan kompetensi bersastra adalah kompetensi-kompetensi yang difokuskan pada kegiatan membaca dan berdiskusi (Utorodewo dan Suryaman, 2007). Dengan karakteristik peserta didik yang menyukai akan tantangan dan penjelajahan serta melawan melalui gagasan-gagasan penting, kegiatan berdiskusi merupakan sarana pengekspresian merekaakan perubahan-perubahan kognitif yang dialaminya.

Kompetensi lain yang amat diminati peserta didik pada masa perkembangan remaja adalah bermain peran. Mungkin pendidik bahasa Indonesia dapat menghadirkan narasumber yang ahli di dalam pementasan drama. Melalui pemeranan, peserta didik pada masa ini akan membangun kesadaran diri dan mendorong untuk melakukan eksperimen melalui sifat-sifat yang baru. Di dalam kegiatan bersastra, fokus kegiatan dapat dimulai dengan pengembangan sifat, perasaan, dan motivasi untuk berprestasi.

Berdasarkan hasil pemetaan terhadap materi bersastra di dalam kurikulum, dapat dikenali lebih jauh mengenai apa yang diperlukan peserta didik di dalam belajar bersastra dan apa yang harus diajarkan kepada mereka. Hasil pemetaan menunjukkan bahwa belajar bersastra diarahkan pengembangan kompetensi bersastra yang sifatnya fungsional dan bermakna.

Kefungsionalan dan kebermaknaan tersebut akan tampak di dalam pemilihan metode pembelajaran. Di dalam sifat kefungsionalannya, pendidik haruslah memperhatikan hal-hal beri- kut ini (Rusyana dan Suryaman, 2005). Pertama, berikan kesempatan kepada peserta didik untuk mengambil bagian dalam peristiwa bersastra yang seluasluasnya. Kedua, berikan kepada peserta didik informasi, praktik, latihan, dan pengalaman-pengalamanbersastra yang sesuai dengan kebutuhan bersastra peserta didik. Ketiga, mengarahkan peserta didik kepada penggunaan kegiatan apresiasi, bukan kepada penguasaan pengetahuan sastra. Keempat, manfaatkan berbagai ragam sastra di dalam tindak/peristiwa bersastra yang terjadi. Kelima, arahkan peserta didik untuk mengembangkan kemahiran bersastranya.Keenam, doronglah kemampuan berpikir bernalar dan kreativitas peserta didik. Di dalam sifat kebermaknaan, pendidik haruslah menekankan pada pemenuhan dorongan bagi peserta didik untuk mengungkapkan ide, pikiran, gagasan, perasaan, dan informasi kepada orang lain, baik secara lisan maupun tertulis.

Pembelajaran sastra, dengan demikian, ditujukan untuk berbagai kepentingan. Beberapa kepentingan di antaranya adalah menjadikan peserta didik mahir membaca dan menulis serta mahir mendengarkan dan melisankan. Jika kepentingan ini tercapai, belajar bersastra akan dirasakan manfaatnya oleh peserta didik oleh karena mereka dipermudah untuk mempelajari bidang-bidang lainnya di sekolah. Dampak ikutan lainnya adalah tumbuhnya kebiasaan membaca yang akhirnya mampu meningkatkan pemahaman dan pengertian tentang manusia dan kemanusiaan, mengenal nilai-nilai, mendapatkan ideide baru, meningkatkan pengetahuan 
sosial budaya, berkembangnya rasa dan karsa, serta terbinanya watak dan kepribadian. Di sinilah esensi pendidikan karakter teridentifikasi dengan jelas di dalam pembelajaran sastra.

Ketersediaan sarana dan prasarana belajar, seperti laboratorium, perpustakaan, ruang kelas, tempat publikasi karya tulis, taman-taman sekolah untuk beraktivitas rohani (seperti membaca dan menulis), ruang teknologi dan informasi, ruang untuk berekspresi (seperti pentas drama, baca puisi dan cerpen, musikalisasi puisi), buku, majalah, serta surat kabar masih menjadi impian bagi banyak sekolah. Rosidi (via Ismail dan Suryaman, 2006:2) menyatakan "selama ini yang menjadi persoalan ialah tidak semua sekolah memiliki perpustakaan, padahal penyediaan bahan bacaan yang praktis dan efisien adalah berupa perpustakaan". Belum lagi ketika dihadapkan kepada persoalan bencana alam yang semakin tinggi intensitasnya. Sarana dan prasarana yang telah ada pun menghilang dan tidak dapat disediakan lagi dalam waktu cepat. Tentulah persoalan ini akan berdampak pada lemahnya pembelajaran bersastra.

Di dalam konteks membaca dan menulis, kurangnya sarana dan prasarana -- khususnya perpustakaan dan buku - akan melemahkan percepatan pengembangan kemampuan baca-tulis. Akibatnya, kemampuan baca-tulis yang bersifat teknis akan terus berlanjut. Padahal, harapan dari pembelajaran bersastra adalah berkembangnya kemampuan baca-tulis dalam pengertian secara fungsional dan budaya sebagai bagian dari pendidikan karakter.
Permasalahan lain yang seringkali menjadi kendala di dalam pembelajaran sastra selama ini di sekolah adalah pendidik kurang mengetahui bagaimana mendapatkan serta menentukan buku-buku sastra tersebut. Oleh karena itu, perlulah kiranya suatu usaha untuk menghimpun buku-buku sastra yang diperlukannya. Di dalam penentuannya diperlukan suatu usaha yang terencana dan terarah, yakni memilih buku karya sastra yang relevan bagi pengembangan karakter peserta didik. Alasannya adalah tidak semua karya sastra dapat dibaca secara merata oleh peserta didik.

Buku merupakan sarana dalam proses pendidikan yang sangat penting. Di samping itu, ditunjang lagi dengan berbagai kenyataan bahwa sampai sekarang buku tidak dapat tergantikan posisinya oleh media lain. Buku juga merupakan media pendidikan yang murah dan dapat dipelajari kembali kapan saja serta di mana saja dengan keuntungan positif, seperti untuk mengasuh, memelihara, dan mengembangkan pikiran, imajinasi, serta kepribadian. Namun, buku juga dapat melumpuhkan atau merusak pikiran, imajinasi, serta kepribadian jika isinya buruk dan tidak sesuai dengan perkembangan kognitif peserta didik. Oleh karena itu, diperlukan proses pemilihan terhadap buku karya sastra Indonesia yang bermutu untuk kegiatan bersastra.

Untuk membangun karakter dan kepribadian peserta didik yang berakhlaq mulia, berkarakter kuat, seperti kreatif, kompetitif, disiplin, menjunjung semangat kebangsaan, serta siap untuk menjadi manusia yang tangguh di era global abad ke-21 dan untuk segera da- 
pat memperbaiki berbagai permasalahan kepribadian dan moral peserta didik yang sedang melanda bangsa akhirakhir ini, diperlukan buku-buku sastra yang memenuhi kriteria yang sesuai untuk peserta didik. Sesuai dengan hakikat karya sastra, materi bersastra di dalam kurikulum, dan pembelajaran bersastra yang diharapkan dapatlah dikemukakan beberapa kriteria pemilihan karya sastra yang mengarah pada pengembangan karakter bagi peserta didik berikut ini. Pertama, bahasanya indah, dengan ekspresi otentik, dan memperkenalkan estetika pada pembacanya sehingga membentuk kepekaan dalam dirinya, yang akan berkembang menjadi empati pada permasalahan kemanusiaan. Kedua, mengharukan pembacanya, dan menyebabkannya merenungkan makna karya tersebut, serta memperoleh kearifan dan pencerahan di dalam: identitas kebangsaan, kreativitas, keberanian berkompetisi, solidaritas kemanusiaan, serta keimanan dan ketaqwaan. Ketiga, membawakan nilainilai luhur kemanusiaan, yang akan mengembangkan empati di dalam diri pembaca terhadap permasalahan manusia. Nilai-nilai luhur tersebut antara lain: akhlaq mulia, sikap lemah-lembut, suka memaafkan, anti kekerasan, disiplin diri, etos kerja, menghargai orangtua dan pendidik, serta mendengar pendapat orang lain. Keempat, mendorong pembacanya untuk berbuat baik kepada sesama manusia dan makhluk lainnya, di dalam berbagai kegiatan pribadi maupun kemasyarakatan.

Berdasarkan paparan tersebut dapatlah dikemukakan bahwa pembelajaran sastra yang mengarah pada pe- ngembangan karakter pesertadidik adalah pembelajaran yang mampu menumbuhkan budaya baca-tulis secara fungsional yang mampu meningkatkan pemahaman dan pengertian tentang manusia dan kemanusiaan, mengenal nilai-nilai, mendapatkan ide-ide baru, meningkatkan pengetahuan sosial budaya, berkembangnya rasa dan karsa, serta terbinanya watak dan kepribadian. Di samping itu, pembelajaran sastra juga haruslah memperhatikan segi-segi yang tepat dan sesuai dengan perkembangan kognitif peserta didik, seperti bahasanya yang indah, mengharukan pembacanya, membawakan nilai-nilai luhur kemanusiaan, serta mendorong pembacanya untuk berbuat baik. Hal ini dimungkinkan oleh karena esensi dari hakikat sastra adalah sebagai media pencerahan mental dan intelektual pembacanya.

\section{PENUTUP}

Berdasarkan analisis mengenai hakikat sastra, materi bersastra di dalam kurikulum, serta pembelajaran bersastra yang diharapkan, dapatlah ditarik beberapa simpulan.

- Secara hakiki sastra merupakan media pencerahan mental dan intelektual peserta didik yang menjadi bagian terpenting di dalam pendidikan karakter, seperti kebangkitan suatu bangsa ke arah yang lebih baik, penguatan rasa cinta tanah air, serta sumber inspirasi dan motivasi kekuatan moral bagi perubahan sosialbudaya melalui kegiatan literasi sehingga budaya baca berkembang.

- Terdapat beragam materi bersastra yang harus diapresiasi siswa, baik 
melaluikegiatan mendengarkan, melisankan, membaca, maupun menulis yang dikembangkan di dalam kurikulum bahasa Indonesia yang mengarah pada pembentukan karakter sebagai bagian terpenting di dalam pendidikan karakter.

- Pembelajaran bersastra yang relevan untuk pengembangan karakter peserta didik adalah pembelajaran yang memungkinkan peserta didik tumbuh kesadaran untuk membaca dan menulis karya sastra yang akhirnya mampu meningkatkan pemahaman dan pengertian tentang manusia dan kemanusiaan, mengenal nilai-nilai, mendapatkan ide-ide baru, meningkatkan pengetahuan sosial budaya, berkembangnya rasa dan karsa, serta terbinanya watak dan kepribadian.

- Untuk membangun karakter dan kepribadian peserta didik yang berakhlaq mulia, berkarakter kuat, seperti kreatif, kompetitif, disiplin, menjunjung semangat kebangsaan, serta siap untuk menjadi manusia yang tangguh dan untuk segera dapat memperbaiki berbagai permasalahan kepribadian dan moral peserta didik yang sedang melanda bangsa akhir-akhir ini, diperlukan buku-buku sastra yang memenuhi kriteria yang sesuai untuk peserta didik, yakni bahasanya indah; mengharukan pembacanya; membawakan nilai-nilai luhur kemanusiaan; serta mendorong pembacanya untuk berbuat baik kepada sesama manusia dan makhluk lainnya.

\section{UCAPAN TERIMA KASIH}

Tulisan sekecil apapun tentulah tidak dapat dipisahkan dari kontribusi orang lain, termasuk artikel ini. Oleh karena itu, izinkan penulis menyampaikan ucapan terima kasih kepada berbagai pihak. Pertama, ucapan terima kasih disampaikan kepada para kontributor yang pemikiran, gagasan, dan temuannya dijadikan bahan rujukan di dalam penulisan artikel ini. Kedua, ucapan terima kasih disampaikan kepada Pusat Perbukuan Depdiknas, khususnya Bapak Dr. Sugijanto, Bapak Drs. Agus Lukman Hakim, M.Sc., dan Ibu Dra. Wahyu Trihartati, M.Pd. yang telah memberikan kepercayaan kepada penulis untuk mengembangkan instrumen pemilihan buku-buku sastra yang relevan untuk peserta didik jenjang SD/ MI, SMP MTs., dan SMAMA untuk koleksi perpustakaan sekolah. Inspirasi artikel ini dimulai dari pengalaman penulis di dalam mengembangkan instrumen yang dimaksud. Ketiga, ucapan terima kasih disampaikan kepada Bapak Dr. (HC) Taufik Ismail yang telah bekerja sama dengan baik di dalam mengembangkan instrumen pemilihan buku-buku sastra diPusat Perbukuan Depdiknas. Keempat, ucapan terima kasih disampaikan kepada Redaktur Jurnal Cakrawala Pendidikan yang telah mempertimbangkan artikel ini untuk dipublikasi pada edisi Dies UNY 2010. Semoga artikel ini dapat menginspirasi para pendidik dan dosen di dalam mengembangkan pembelajaran bersastra sehingga pendidikan karakter peserta didik berkembang secara signifikan. 


\section{DAFTAR PUSTAKA}

Abrams, M.H. 1981. A Glossary of Literary Lamps. New York: Holt Rinehart \& Winston.

Effendi, S. 2004. Bimbingan Apresiasi Puisi. Jakarta: Pustaka Jaya.

Elley, W.B. 1992. "How in the World Do the Students Read?", The International Association for the Evaluation of Education Achievement (IEA).

Global Monitoring Report. 2006. Literacy for Life.

Herfanda, A.Y. 2008. "Sastra sebagai Agen Perubahan Budaya" dalam Bahasa dan Budaya dalam Berbagai Perspektif, Aanwar Effendi, ed. Yogyakarta: FBS UNY dan Tiara Wacana.

Harjasujana, A.S. 1988. "Nusantara yang Literat: Secercah Sumbang Saran terhadap Upaya Peningkatan Mutu Pendidikan di Indonesia", Pidato Pengukuhan Pendidik Besar pada IKIP Bandung.

Ismail, T. 2003. "Agar Anak Bangsa Tak Rabun Membaca tak Pincang Mengarang". Pidato Penganugerahan Gelar Kehormatan Doctor Honoris Causa di bidang Pendidikan Sastra, Universitas Negeri Yogyakarta.

Ismail, T dan M. Suryaman. 2006. Instrumen Pemilihan Buku Sastra untuk Perpustakaan Sekolah. Jakarta: Pusat Perbukuan Depdiknas.

Kleden, I. 1999. "Buku di Indonesia: Perspektif Ekonomi tentang Kebudayaan" dalam Buku dalam In- donesia Baru. Editor Alfons Taryadi. Jakarta: YOI.

Kurniawan, Kh. Dan I. Cahyani. 2008. Panduan Pendidik Bahasa Indonesia Sekolah Dasar, Jakarta: Pusat Perbukuan Depdiknas.

Peraturan Pemerintah Nomor 19 Tahun 2005 tentang Standar Nasional Pendidikan, Jakarta: Fokus Media.

Peraturan Menteri Pendidikan Nasional Republik Indonesia Nomor 22 Tahun 2006 tentang Standar Isi, Jakarta, 2006.

Piaget, J. 1971. Science of Education and the Psychology of the Child. New York: Viking.

Pikiran Rakyat, 5 Agustus 2005. http:// www.pikiran-rakyat.com/cetak/2005/0805/04/0401.htm Diakses 4 November 2006.

Rusyana, Y. dan M. Suryaman. 2005. Pedoman Penulisan Buku Teks Pelajaran Bahasa Indonesia SD, SMP, dan $S M A$. Jakarta: Pusat Perbukuan Depdiknas.

UNESCO. 2003. Program for International Student Assessment (PISA) pada tahun 2003.

Utorodewo, F.N. dan M. Suryaman. 2007. Pedoman Penilaian Buku Teks Pelajaran Bahasa Indonesia SMP dan SMA. Jakarta: Pusat Perbukuan Depdiknas.

World Bank. 1998. Indonesia: Book and Reading Development Project, Staff, Appraisal, May. 